\title{
Epiphytic lichens of Conguillío National Park, southern Chile
}

\section{Líquenes epífitos en el Parque Nacional Conguillío, sur de Chile}

\author{
Cecilia Rubio ${ }^{1 *}$, Marcelo SaAvedra² ${ }^{2}$ Mauricio Cuéllar ${ }^{1}$, Rodrigo Diaz $^{1} \&$ Wanda Quilhot $^{1}$ \\ ${ }^{1}$ Herbario de Líquenes UV, Departamento de Química y Recursos Naturales, Facultad de Farmacia, Universidad de Valparaíso. \\ ${ }^{2}$ Corporación Nacional Forestal, Región de la Araucanía, Bilbao 931, $2^{\circ}$ piso, Temuco. \\ *cecilia.rubio@uv.cl
}

\begin{abstract}
One hundred and thirty eight epiphytic lichen species in 40 genera, are recorded from Conguillio National Park (38 $30^{\prime}-$ $\left.38^{\circ} 50^{\prime} \mathrm{S} ; 71^{\circ} 30^{\prime}-71^{\circ} 55^{\prime} \mathrm{W}\right)$, with predominancy of typically southern South American species. Lichen diversity is high, about $9 \%$ of the lichen mycobiota from Chile, due mainly to species of the genera Bunodophoron, Menegazzia, Nephroma, Pannaria, Protousnea and Pseudocyphellaria. Levels of endemism are rather high (nearly $40 \%$ ); also austral and cosmopolitan species, about $19 \%$ and $16 \%$ respectively, are the most representative biogeographical elements in the Park.

KeYwoRDs: Endemism, epiphytes, lichens, phorophytes, wild protected areas.

\section{RESUMEN}

Se registran para la micobiota liquénica epífita en el Parque Nacional Conguillío (38³0’ $38^{\circ} 50^{\prime}$ S; $71^{\circ} 30^{\prime}-71^{\circ} 55^{\prime}$ W) 183 especies en 40 géneros con predominancia de especies típicas del sur de Sudamérica. La diversidad es elevada, alrededor del $9 \%$ de la flora liquénica del país debido, principalmente, a especies de los géneros Bunodophoron, Menegazzia, Nephroma, Pannaria, Protousnea and Pseudocyphellaria. Los niveles de endemismo son elevados, cerca del $40 \%$; los líquenes australes y cosmopolitas, $19 \%$ y 16\% respectivamente, son los elementos biogeográficos más representativos en el Parque.
\end{abstract}

Palabras clave: Endemismo, epífitos, líquenes, forófitos, áreas silvestres protegidas.

\section{INTRODUCTION}

Lichens play a very important role in nutrient cycling in the rainforest ecosystem and are therefore essential to the well-being of one of the most useful and important Chile's natural resources. In the forested areas on the western slopes of the Andean mountain range, from latitude $36^{\circ} \mathrm{S}$ to $49^{\circ} \mathrm{S}$, the development of the lichen mycobiota is characterized by both high species diversity and high biomass where epiphytic lichens are dominant (Galloway 1998, Quilhot et al. 2012).

Lichens are the most conspicuous epiphytes in trees and shrubs in Conguillio National Park (38 30' - 38 50 ' S; 71³0' - $71^{\circ} 55^{\prime} \mathrm{W}$ ) located in the Araucanía Region (IX Region) at the foot of the Andean mountain range. Conguillio is part of the Valdivian temperate forests ecoregion (Dinerstein et al. 1995). Also it is included in the Araucarias Biosphere Reserve created by UNESCO to protect forests, biodiversity and habitats in one of the most threatened areas in the country.
The dominant feature in the Park is Llaima volcano $(3,125 \mathrm{~m})$; its eruptions and those of Sierra Nevada volcano (2,544 m), currently inactive, have modelled the landscape giving origin to lakes, lagoons, rivers and scoria boulders in lava flows. Climate in the area is warm-temperate, with mean temperatures of $15,1^{\circ} \mathrm{C}$ in summer and $6,0{ }^{\circ} \mathrm{C}$ in winter; precipitations range between 1,500 to $2,500 \mathrm{~mm} /$ year. From 1,400 $\mathrm{m}$ of altitude, temperatures drop below 0 ${ }^{\circ} \mathrm{C}$ and precipitations increase to $3,000 \mathrm{~mm} /$ year.

According to Gajardo (1983), the Conguillio National Park can be considered as a natural reserve representing the Andean-Patagonian forests and the Andean deciduous forests. The forest types have been described by Arriagada \& Cares (1996) and Mahncke (1997); the main forest species are Araucaria araucana (Molina) K. Koch., Austrocedrus chilensis (D. Don) Pic.Ser. et Bizz., Nothofagus antarctica (G. Forst.) Oerst., N. pumilio (Poepp. et Endl.) Krasser, N. dombeyi (Mirb.) Oerst. and N. obliqua (Mirb.) Oerst.

Major contributions to present knowledge of lichens 
from Conguillio have been made principally by Bjerke (2001, 2005), Bjerke \& Elvebakk (2001), Bjerke et al. (2003a,b), Elvebakk (2007) and Elvebakk et al. (2007, 2010), Galloway (1992, 1994, 2007), Galloway \& GuzmánGrimaldi (1988), Galloway \& James (1987), Galloway \& Jørgensen (1995), Galloway et al. (2006), Wedin (1995), White \& James (1988). Currently there is not a compilation about the lichen mycobiota in the Park. This report contributes to better understand the epiphytic lichen flora of Conguillio including data about substrate, ecological requirementns of the habitat, distribution and biogeographical affinities.

\section{MATERIAL AND METHODS}

Compilation of the lichen mycobiota from Conguillio National Park follows the published lichen records and lichen inventories performed in the last 30 years (Quilhot, pers. comm.). Field work and logistic support was assisted by CONAF IX Region, and funded by grants provided by Dirección de Investigación, Universidad de Valparaíso.

Identification of the species was undertaken in collaboration with David Galloway (Landcare Research
Ltd., New Zealand), Jarle Werner Bjerke and Arve Elvebakk (University of Tromsø, Norway) and Peter W. James (The British Museum, London).

Field studies and collecting trips were performed in different sites in the Park, mainly in the vicinity of Llaima volcano (Fig. 1). Target epiphytes were considered to be all species growing on trees and shrubs between ca. 0 - 2 $\mathrm{m}$ height.

Laboratory studies were performed on material collected including lichen specimens from 1978 to 2010.

Comparisons with herbarium material were performed. Observations and measurements of anatomical and external features were performed using a Nikon model 104 microsocope, and a Leica DMLS stereomicroscope. Thin sections of thallus -being cut them by hand- were mounted in water, followed by $10 \% \mathrm{KOH}$; acid fuchsin and methylene blue were also used.

The names of the species are given in alphabetical order. The list of taxa includes all lichen material determined at species level. Nomenclature follows Galloway \& Quilhot (1998), and more recent taxonomic treatments. Lichen material is deposited in the Herbarium (UV) of the Universidad de Valparaíso.

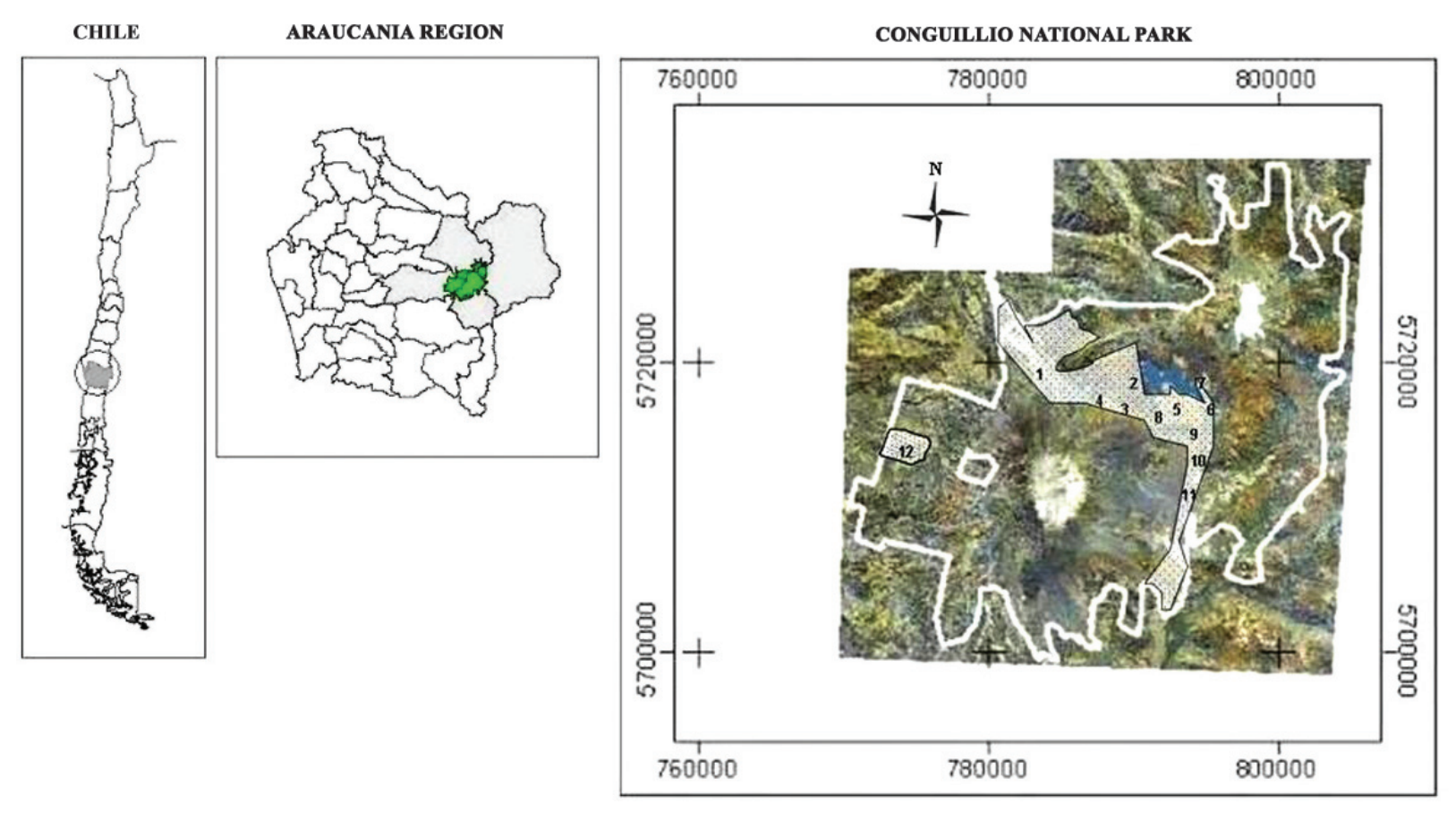

Figure 1. Study area in Conguillio National Park, Chile. (1) Laguna Captrén, (2) Los Carpinteros, (3) Centro de Información, (4) Velo de la Novia, (5) Cabañas del Lago, (6) Playa Linda, (7) Road to Sierra Nevada, (8) El Hoyón, (9) La Caseta, (10) Laguna Arcoiris, (11) Laguna Verde, (12) Los Paraguas, (LC) Lago Conguillio.

Figura 1. Áreas de studio en el Parque Nacional Conguillío, Chile. (1) Laguna Captrén, (2) Los Carpinteros, (3) Centro de Información, (4) Velo de la Novia, (5) Cabañas del Lago, (6) Playa Linda, (7) Camino a Sierra Nevada, (8) El Hoyón, (9) La Caseta, (10) Laguna Arcoiris, (11) Laguna Verde, (12) Los Paraguas, (LC) Lago Conguillío. 


\section{RESULTS AND DISCUSSION}

Conguillio National Park is part of the Valdivian temperate forests ecoregion with predominancy of typically southern South American species. The rich and diverse epiphytic flora -138 species in 40 genera- is a consequence of the variety of ecosystems in the area due to geographic and climatic features. Lichen species have increased from 1383 in the last decades (Galloway \& Quilhot 1998) to 1450 species up to date, suggesting that epiphytic lichen diversity is high; 9 $\%$ of the Chilean lichen mycobiota is present in the Park.

The most representative are: Bunodophoron, Leptogium, Menegazzia, Nephroma, Pannaria, Protousnea, Pseudocyphellaria, Psoroma and its related genera.

Sixteen species of Menegazzia have been registered in Conguillio; except $M$. magellanica and M. megalospora from southernmost Chile. M. globulifera, one of the most frequent species in the genera, grows better in rather dry, open and sunny environments (Bjerke et al. 2003a, Quilhot et al. 2012); conversely, $M$. wilsonii and $M$. violascens are found in very humid and shady sites. Other Hypogymniaceae, the genus Hypogymnia, is represented by four species.

Protousnea, originally described as a subgenus of Usnea, and elevated by Krog (1976) to generic level, is one of the most conspicuous genus in the Park, and includes seven species, six of which grow on trees and shrubs at altitudes ranging from 600 to $1,500 \mathrm{~m}$. The species show high affinities to light; thalli are often more abundant in the canopy than on trunks or lower branches. The genus, an endemic element of southern South America, has a very limited distribution; in Chile it is known from the Andean foot-hills in the VII Region to Navarino Island. A new species, Protousnea fibrillatae Calvelo, Socker-Wörgoter, Elix \& Stenroos, has been recently described in Argentina (Calvelo et al. 2005).

The family Pannariaceae is represented by the genera Degeliella, Pannaria, Parmeliella, Psoroma, Psorophorus and Xanthopsoroma. In the last few years, Psoroma was a collective name for Pannariaceae species with thalline excipuli. At present, using phylogenetic analysis, foliose species have been included in Pannaria (Ekman \& Jørgensen 2002, Elvebakk \& Galloway 2003, Passo \& Calvelo 2006), and in the new genera Psorophorus and Xanthopsoroma (Elvebakk et al. 2010)

Species of the family are currently found in areas of Central-South Chile (Bío Bío to Magallanes). Several species of the family registered in Conguillio are found on bark of trees in pure forests of Austrocedrus chilensis in Laguna del Laja National Park, considering that this wild protected area could be the dispersion center of Pannariaceae in the country (Rubio \& Quilhot, pers. obs.). Trunks and primary branches of $A$. chilensis in the scoria boulders in lava flows are very rich in Pannaria conoplea, $P$. farinosa and P. tavaresii.

The genus Parmeliella is represented by $P$. nigrocincta, a rather common lichen species, and $P$. granulata considered as an infrequent lichen species. Observations in other wild protected areas and the knowledge of species distribution in the country have shown that ecological features, in terms of micro and macrohabitats, generate a concentration of Pannariaceae (20 species) in Conguillio National Park.

The environment is also favourable to the growth of Pseudocyphellaria. Galloway (1992) considers major factors controlling distribution of species such as: rainfall, an adequate illumination, with latitude, altitude and mean annual temperature; these factors would influence on the growth of numerous species of the genus; 54 species have been registered in Chile (Galloway 1992, Bjerke 2003b), 54 $\%$ of them occur in the Park. Pseudocyphellaria coriifolia, $P$. crocata, $P$. granulata, $P$. hirsuta, $P$. faveolata and $P$. nudata are common species in different areas in the Park.

Seven species of the genus Sticta have been collected in Conguillio. S. caulescens is the most common and grows in very humid and shady sites, as an epiphyte in the lower part of trunks of different phorophytes. The other species of the genus are found occasionally in the base of trunks.

White \& James (1988) described sixteen species of Nephroma in Chile; nine of which have been collected in Conguillio. N. antarcticum var. antarcticum and $N$. cellulosum var. cellulosum are the most frequent species in the genus. Their ecological requirements seem to be precarious or they have a high degree of plasticity to tolerate environmental changes in the habitat. Also they have the largest distribution including Juan Fernández Archipelago.

Coelopogon epiphorellus, Platismatia glauca and Tukemannopsis chlorophylla, are species currently found in steppe areas in Aysén (Quilhot et al. 2012) which are very common on Nothofagus spp. and Araucaria araucana in the area of Laguna Captrén.

Almost all the species of Bunodophoron registered in Chile are present in Conguillio National Park on trunks of large trees.

Teloschistes chrysophthalmus and Physma chilensis are infrequent in Conguillio. P. chilensis is currently found in Araucanía Region, particularly in the Malleco National Reserve at 500 to $800 \mathrm{~m}$ altitude, also the species was collected in Laguna Amargo, at $800 \mathrm{~m}$ altitude near Parral. Conversely, T. chrysophthalmus is found on coastal zones in central and south Chile; the species has not been registered in areas of high altitude near the mountain range.

Collemataceae are poorly represented. Collema glaucophthalmum is relatively frequent on bark of large trees in very shady sites. Species of Leptogium are occasionally found.

Most lichens frequently occupy wide unexplored distribution areas in terrestrial ecosystems with frequent intercontinental disjunctions. Due to the above, distribution maps are usually incomplete and the composition of lichen floras of remote regions is often poorly known. These 
problems and a lack of fossil records have hindered studies on the biogeography of lichens in the past (Printzen 2008). These considerations are important to assess the distribution patterns of some lichen species in Conguillio. Endemic elements from southern South America -nearly $40 \%-$, austral $(18 \%)$ and cosmopolitan $(16 \%)$ are predominant in the Park.

\section{CONCLUSIONS}

The temperate high-altitude forests along the ChileanArgentinean border appear to be a climatic equivalent of antiboreal forests at low altitudes and south latitude $48^{\circ} \mathrm{S}$ (Bjerke et al. 2003a). Conversely, lichens that are commonplace at low altitude in antiboreal zones are confined to higher altitude in temperate areas, as occurs in Conguillio. Protousnea grows between 600 and 1,300 $\mathrm{m}$ in Conguillio $\left(38,3^{\circ} \mathrm{S}\right)$; the species are found from 200 to $1,200 \mathrm{~m}$ in steppe forests in Aysén, at latitude $47,3^{\circ} \mathrm{S}$ (Quilhot et al. 2012), and at sea level in Navarino Island, at $55,04^{\circ} \mathrm{S}$ (Redón \& Quilhot 1977). The genus Menegazzia is very common in southern Chile. Sixteen species have been collected in temperate forests in Conguillio; all the species registered in Chile (18) are found at sea level in Laguna San Rafael National Park in Aysén Region at 46,4 $\mathrm{S}$ (Quilhot et al. 2002), while in steppe areas, at high altitude, the number of species noticeably decreased.

Lichen diversity and biomass have diminished in the last three decades (Quilhot, pers. obs.). Tourism affects the environment including phorophytes and epiphytes. Large thalli of Pannaria pallida and P. farinosa, having $25 \mathrm{~cm}$ diameter or more, have disappeared; also Pseudocyphellaria scabrosa, P. encoensis, P. pluvialis and P. santessonii are difficult to find today in the habitats where they were characteristics.

Nevertheless, field observations and lichen collections in wild protected areas in Araucanía Region (Quilhot \& Rubio, unpublished) demonstrate that the major epiphytic lichen diversity is found in Conguillio National Park.

\section{LIST OF THE LICHEN SPECIES}

\author{
Alectoria ochroleuca (Hoffm.) A. Massal. \\ Circumpolar. The species grows on bark of large trees, \\ especially on bark of Araucaria araucana. In Chile is \\ known from Llanquihue (X Region) to Navarino Island (XII \\ Region). \\ (Redón 1974, Brodo \& Hawksworth 1977, Redón \& Quilhot \\ 1977).
}

Bunodophoron australe (Laurer) A. Massal.

The species is known from Argentina, Chile, New Zealand,
Tasmania, New Caledonia and Hawaii. It is currently found on bark of Araucaria araucana and Nothofagus spp. in humid and shady habitats on the roadside to Velo de la Novia. In Chile is known from Nahuelbuta National Park (IX Region) to Magallanes (XII Region).

(Wedin 1995, Elix \& McCarthy 1998).

Bunodophoron dodgei (Ohlsson) Wedin

Endemic to southern South America. The species is currently found on trunks of Araucaria araucana and old specimens of Nothofagus spp. in rather shady places, especially in El Hoyón and La Caseta. In Chile is known from Malleco (X Region) to Magallanes (XII Region).

(Wedin 1995).

Bunodophoron imshaugii (Ohlsson) Wedin

The species is widespread in the Southern Hemisphere (Argentina, Chile, New Caledonia, New Zealand and Tasmania). It is found in shady sites on bark of Araucaria araucana-Nothofagus forests in the area between the Centro de Información and Conguillio Lake. In Chile is known from Nahuelbuta National Park (IX Region) to Magallanes (XII Region).

(Wedin 1995, Elix \& McCarthy 1998).

Bunodophoron insigne (Laurer) Wedin

The species is known in Argentina, Chile, New Zealand, South Australia and Solomon Islands. It grows on trunks of Araucaria araucana and Nothofagus spp. on the roadside to Velo de la Novia. In Chile is known from Nahuelbuta National Park (IX Region) to Magallanes (XII Region). (Wedin 1995, Elix \& McCarthy 1998).

Bunodophoron patagonicum (C.W. Dodge) Wedin Austral. The species is found on trunks of large trees. Epiphyte in humid and shaded sites on Araucaria araucana and Nothofagus spp. In Chile is known in Juan Fernández Archipelago and from Nahuelbuta National Park (IX Region) to Magallanes (XII Region).

(Wedin 1995, Elix \& McCarthy 1998).

Bunodophoron ramuliferum (I.M. Lamb) Wedin The species is present in southernmost South America (Argentina and Chile), New Zealand, Australia and New Caledonia. It is common on trunks in large trees in humid and shaded habitats. In Chile is known in Juan Fernández Archipelago, and from Malleco (IX Region) to Magallanes (XII Region).

(Wedin 1995, Elix \& McCarthy 1998).

Bunodophoron scrobiculatum (C. Bab) Wedin

The species is widely distributed in the Southern Hemisphere (southern South America, New Zealand and Tasmania). It is found on trunks in large trees, particularly in Araucaria 
araucana. In Chile is known in Juan Fernández Archipelago and from Malleco (IX Region) to Magallanes (XII Region). (Wedin 1995).

Coccotrema cucurbitula (Mont.) Müll. Arg.

The species is known in temperate oceanic or suboceanic regions around the Pacific Ocean. It is found in the Park on trunks and twigs of forest species. In Chile is known from Malleco (IX Region) to Navarino Island and the Antarctic Territory (XII Region).

(Redón \& Quilhot 1977, Messuti 1996, Øvstedal \& Lewis Smith 2001).

Coelopogon epiphorellus (Nyl.) Brusse \& Kärnefelt South American-African element. The species is widely distributed on bark of Araucaria araucana, Nothofagus spp., other forest trees, shrubs, and also on rocks. In Chile is known in La Campana National Park (V Region), and from Altos de Lircay National Reserve (VII Region) to Navarino Island and the Antarctic Territory (XII Region).

(Redón \& Quilhot 1977, Redón \& Walkowiak 1978, Brusse \& Kärnefelt 1991, Øvstedal \& Lewis Smith 2001).

Coenogonium luteum (Dicks.) Kalb \& Lücking

Cosmopolitan; foliicolous specimens have been reported from tropical regions. It was collected on bark of tree trunks in humid and shaded sites. In Chile is known from Federico Albert National Reserve (VII Region) to Aysén (XI Region). (Lücking \& Kalb 2000).

\section{Collema glaucophthalmum $\mathrm{Nyl}$.}

Pantropical. The species is an epiphyte of trees and shrubs in rather humid and shaded sites. It is currently found in the area between Centro de Información and Conguillio Lake. Also common on bark of Nothofagus antarctica in El Hoyón. In Chile is known from Altos de Lircay National Reserve (VII Region) to Aysén (XI Region).

(Filson 1992).

Degeliella versicolor (Müll. Arg.) P.M. Jørg.

Austral. The species is an epiphyte of trees and shrubs in shaded forests. It has been collected on bark of Nothofagus pumilio on the roadside to Velo de la Novia. In Chile is known from Los Queñes (VII Region) to Tierra del Fuego (XII Region).

(Galloway \& James 1985, Jørgensen 2004).

Dictyonema glabratum (Spreng.) D. Hawksw.

Pantropical. The species is found amongst mosses and shrubs, in shady and humid habitats in mixed AraucariaNothofagus forests. In Chile is known from Putre (I Region), Cerro Moreno (II Region), Juan Fernández Archipelago, and from Altos de Lircay National Reserve (VII Region) to Magallanes (XII Region).
(Parmasto 1978).

Everniastrum sorocheilum (Vain.) Hale ex Sipman Austral-pantropical. The species is an epiphyte of trees and shrubs in open sites, infrequent in the Park. In Chile is known from Valparaíso (V Region) to Curicó (VII Region), and from Temuco (IX Region) to Magallanes (XII Region). (Sipman 1986, Adler \& Calvelo 2002).

Gowardia nigricans (Ach.) P. Halonen, L. Myllys, S. Velmala \& H. Hyvärinen.

Circumpolar. The species is an epiphyte of large trees in habitats of high humidity. It has been collected on bark of Araucaria araucana in Laguna Captrén. In Chile is known from Valdivia (X Region) to Navarino Island (XII Region). (Brodo \& Hawksworth 1977, Redón \& Quilhot 1977, Halonen et al. 2009).

Hypogymnia mundata (Nyl.) Rassad.

Austral. The species is an epiphyte on Nothofagus spp., particularly on Nothofagus antarctica, in shady sites. In Chile is known from Malleco (IX Region) to Magallanes (XII Region).

(Elix 1992).

Hypogymnia subphysodes (Kremp.) Filson var. subphysodes (Kremp.) Filson

Austral. The species is an epiphyte on bark of Nothofagus spp. and Austrocedrus chilensis, in open sites, and in scoria boulders on lava flows near Laguna Verde. In Chile is known in Fray Jorge National Park (IV Region), and from Altos de Lircay National Reserve (VII Region) to Magallanes (XII Region).

(Elix 1992).

Hypogymnia turgidula (Bitter) Elix

Austral. The species is an epiphyte of trunks and twigs in Nothofagus forests. It was collected near Laguna Captrén. In Chile is known from Malleco (IX Region) to Magallanes (XII Region).

(Elix 1992).

Hypotrachyna brevirhiza (Kurok.) Hale

Pantropical and extending to temperate areas of Argentina and Chile. The species is an epiphyte of Araucaria araucana, Nothofagus spp. and shrubs in humid forests, such as on the road to Los Carpinteros. In Chile is known from Mocha Island (VIII Region) to Magallanes (XII Region).

(Nash III et al. 2002, Quilhot et al. 2010).

Hypotrachyna laevigata $(\mathrm{Sm}$.) Hale

Cosmopolitan. The species is an epiphyte of trees and shrubs in open sites with high direct solar radiation. It has been collected in Laguna Captrén, El Hoyón and Laguna 
Arcoiris. In Chile is known from Altos Lircay National Reserve (VII Region) to Magallanes (XII Region).

(Hale 1974, Nash III et al. 2002).

Hypotrachyna sinuosa (Sm.) Hale

Cosmopolitan. The species is an epiphyte of trees and shrubs, particularly in Araucaria-Nothofagus forests in open sites around Laguna Captrén, El Hoyón, La Caseta and Laguna Arcoiris; also on bark of Austrocedrus chilensis in scoria boulders on lava flows near Laguna Verde. In Chile is known from Río de Los Cipreses National Reserve (VI Region) to Magallanes (XII Region).

(Hale 1974, Nash III et al. 2002).

Leptogium australe (Hook. f. \& Taylor) Müll. Arg.

Apparently endemic to southern South America. The species is an epiphyte of shrubs, in humid and rather shaded habitats. In Chile is known from Mocha Island (VIII Region) to Magallanes (XII Region).

(Galloway \& Jørgensen 1995, Quilhot et al. 2010).

Leptogium azureum (Sw. ex Ach.) Mont.

Cosmopolitan. The species is an epiphyte of trees and shrubs in shaded humid conditions. In Chile is known in Cerro Moreno (II Region), Fray Jorge National Park (IV Region), Juan Fernández Archipelago, La Campana National Park (V Region), and from Mocha Island (VIII Region) to Aysén Region.

(Redón \& Walkowiak 1978, Galloway \& Jørgensen 1995; Quilhot et al.2010).

\section{Leptogium decipiens P.M. Jørg.}

Endemic to southern South America. An epiphyte of trees and shrubs in humid rainforests. It was collected on the road to Los Carpinteros. In Chile is known from Mocha Island (VIII Region) to Magallanes (XII Region).

(Galloway \& Jørgensen 1995, Quilhot et al. 2010).

\section{Leptogium juressianum C. Tavar.}

The species is known in western Europe, east Africa and northern Andes. It is an epiphyte of twigs and shrubs both in shaded, humid forests. In Chile is known from Puyehue (X Region) to Aysén (XI Region).

(Galloway \& Jørgensen 1995).

\section{Leptogium laceroides De Leds.}

The species is known in Mexico, Tristán de Cunha, east Africa and New Zealand. An epiphyte of shrubs and trees both in shaded, humid rainforests. Collected in the area of the Centro de Información. In Chile is known from Conguillio National Park to Aysén (XI Region).

(Galloway \& Jørgensen 1995).

Melanohalea ushuaiensis (Zahlbr.) Essl.
The species is known in southern South America and Antarctica. It is an epiphyte in Nothofagus spp. near Laguna Verde. In Chile is known from Termas de Chillán (VIII Region) to Navarino Island and the Antarctic Territory (XII Region).

(Redón \& Quilhot 1977, Øvstedal \& Lewis Smith 2001, Blanco et al. 2004).

Menegazzia chrysogaster Bjerke \& Elvebakk

Endemic to southern South America. It is an epiphyte of trees and shrubs in low to medium light conditions. It has been collected on bark of Nothofagus spp. in Laguna Captrén. In Chile is known from Termas de Chillan (VIII Region) to Magallanes (XII Region).

(Bjerke \& Elvebakk 2001, Bjerke et al. 2003a).

Menegazzia cincinnata (Ach.) Bitter

Endemic to southern South America. It grows in open sites on bark and twigs of Nothofagus antarctica, on the roadside to El Hoyón and La Caseta. In Chile is known from Termas de Chillán (VIII Region) to Navarino Island (XII Region). (Redón \& Quilhot 1977, Bjerke 2005).

Menegazzia dispora $\mathrm{R}$. Sant.

Endemic to southern South America. The species is an epiphyte of Araucaria araucana and Nothofagus spp. in rather shaded environments. It has been collected in Laguna Captrén. In Chile is known from Cautín (IX Region) to Tierra del Fuego (XII Region).

(Bjerke 2005).

Menegazzia fumarprotocetrarica Calvelo \& Adler

Endemic to southern South America. It is found in fairly open forests on bark of Araucaria araucana and Nothofagus spp. in Laguna Captrén. In Chile is known from Mocha Island (VIII Region) to Magallanes (XII Region).

(Adler \& Calvelo 1996, Bjerke et al. 2003a, Quilhot et al. 2010).

Menegazzia globulifera R. Sant.

Panaustral. The species is epiphyte of trees and shrubs in light exposed relatively dry vegetation. It has been collected on bark of Nothofagus spp. and shrubs in Laguna Captrén, El Hoyón and Playa Linda. In Chile is known from Termas de Chillán (VIII Region) to Navarino Island (XII Region). (Redón \& Quilhot 1977, Bjerke et al. 2003a, Quilhot et al. 2010).

Menegazzia hollermayeri (Räsänen) R. Sant.

Endemic to southern South America. The species is infrequent in the Park, growing on bark of Nothofagus spp. in open sites. In Chile is known from Malalcahuello National Reserve (IX Region) to Aysén (XI Region).

(Bjerke 2005, Quilhot et al. 2012). 
Menegazzia kawesqarica Bjerke \& Elvebakk

Endemic to southern South America. It is an epiphyte of large trees, with fairly high direct solar radiation; it is also common on shaded rock outcrops. The species is mainly found in Laguna Captrén on bark of Nothofagus spp. In Chile is known from Nahuelbuta National Park (IX Region) to Magallanes (XII Region).

(Bjerke \& Elvebakk 2001, Bjerke et al. 2003a).

Menegazzia neozelandica (Zahlbr.) P. James

Austral. The species is an epiphyte of trees and shrubs. It was collected near Laguna Captrén on bark of Araucaria araucana and Nothofagus spp. In Chile is known in Fray Jorge National Park (IV Region), Juan Fernández Archipelago, and from Nahuelbuta National Park (IX Region) to Magallanes (XII Region).

(Bjerke et al. 2003a).

\section{Menegazzia norsorediata Adler \& Calvelo}

Austral. The species is an epiphyte of Nothofagus spp. and shrubs, in microhabitats with variable light conditions. In Chile is known from Nahuelbuta National Park (IX Region) to Magallanes (XII Region).

(Adler \& Calvelo 1996, Bjerke et al. 2003a).

Menegazzia sanguinascens (Räsänen) R. Sant.

Austral. The species is an epiphyte of large trees in habitats with high direct solar radiation; it is also common on shaded rock outcrops. It is found in mixed Araucaria- Nothofagus forests in Laguna Captrén, El Hoyón, La Caseta and Laguna Arcoiris. In Chile is known from Nahuelbuta National Park (IX Region) to Navarino Island (XII Region). (Redón \& Quilhot 1977, Bjerke et al. 2003a).

Menegazzia subpertusa P. James \& D.J. Galloway Austral. The species is an epiphyte of Nothofagus spp. in rather sunny and dry microhabitats. In Chile is known from Termas de Chillán (VIII Region) to Magallanes (XII Region).

(Galloway 1983, Bjerke et al. 2003a).

Menegazzia tenuis R. Sant.

Endemic to southern South America. The species is infrequent in the Park. It has been collected on bark of Nothofagus pumilio in a deep shaded habitat of high humidity in the roadside to Velo de la Novia. In Chile is known from Melipeuco and Icalma (IX Region) to Magallanes (XII Region).

(Bjerke et al. 2003a).

Menegazzia valdiviensis (Räsänen) $R$. Sant.

Endemic to southern South America. The species is an epiphyte on trees and shrubs, often in understory vegetation, avoiding the most shaded habitats. It has been collected on bark of Araucaria araucana and Nothofagus spp. in Laguna Captrén and in N. antarctica in El Hoyón. In Chile is known from Nahuelbuta National Park (IX Region) to Magallanes (XII Region).

(Bjerke et al. 2003a).

Menegazzia violascens (Räsänen) Bjerke

Endemic to southern South America. The species is an epiphyte on trees and shrubs in very humid and shaded sites, currently found on bark of Nothofagus pumilio, particularly on the roadside from Centro de Infomaciones to Laguna Captrén and in Playa Linda. In Chile is known from Nahuelbuta National Park (IX Region) to Navarino Island (XII Region).

(Bjerke 2005).

Menegazzia wandae Bjerke

Endemic to southern South America. The species is an epiphyte of trees in moderate to dense shade habitats. It was collected on bark of Nothofagus antarctica in El Hoyón and in Laguna Captrén. In Chile is known from Mocha Island (VIII Region) to Aysén (XI Region).

(Bjerke 2001, Bjerke et al. 2003a, Quilhot et al. 2010, 2012).

Menegazzia wilsonii (Vain. ex Räsänen) Bjerke

Endemic to southern South America. The species grows on bark of trees and shrubs, also on mosses in shady and more light-open rainforests. It has been collected on bark of Araucaria araucana and Nothofagus spp. in Laguna Arcoiris and in a very humid site near Laguna Verde. In Chile is known from Termas de Chillán (VIII Region) to Tierra del Fuego (XII Region).

(Bjerke 2005).

Metus efflorescens D. J. Galloway \& P. James

Endemic to southern South America. The species is found on living and dead trees, also on rocks in open sites. In Chile is known from Conguillio National Park to Magallanes (XII Region).

(Galloway \& James 1987, Stenroos 1995).

Metus pileatus (Mont.) D.J. Galloway \& P. James Endemic to southern South America. The species is found on bark or decorticated wood, usually over mosses and hepatics in moist, shaded sites. In Chile is known in Juan Fernández Archipelago and from Conguillio National Park to Magallanes (XII Region).

(Galloway \& James 1987, Stenroos 1995, Messuti et al. 2007).

Nephroma analogicum $\mathrm{Nyl}$.

Endemic to southern South America. The species is an epiphyte of trees and shrubs in moist sites and in highlight conditions. It was collected in Los Paraguas on bark 
of Nothofagus spp. In Chile is known in Juan Fernández Archipelago and from Conguillio National Park to Tierra del Fuego (XII Region).

(White \& James 1988).

\section{Nephroma antarcticum (Jaq.) Nyl. var. antarcticum}

Endemic to southern South America. The species is an epiphyte of trees and shrubs, also on rocks in a wide range of light conditions. It is currently found on bark of Araucaria araucana, Nothofagus spp. and other forest species. In Chile is known in Fray Jorge National Park (IV Region), Juan Fernández Archipelago, and from Altos de Lircay National Reserve (VII Region) to Navarino Island (XII Region). (Redón \& Quilhot 1977, White \& James 1988).

Nephroma cellulosum (Ach.) Ach. var. cellulosum

Austral. The species is an epiphyte in mixed Araucaria araucana and Nothofagus forests and shrubs in humid sites, widely distributed in the Park. In Chile is known in Juan Fernández Archipelago and from Valparaíso (V Region) to Navarino Island (XII Region).

(Redón \& Quilhot 1977, White \& James 1988).

Nephroma cellulosum (Ach.) Ach. var. isidioferum J.S. Murray

Austral. The species grows on Nothofagus spp. and shrubs in humid and shady sites. It was collected in Los Paraguas. In Chile is known from Malalcahuello National Reserve (IX Region) to Navarino Island (XII Region).

(White \& James 1988, Quilhot et al. 2012).

\section{Nephroma chubutense I.M. Lamb}

Endemic to southern South America. The species is an epiphyte in Nothofagus forests, also on fallen trunks; restricted to very humid habitats. The species has been collected in Los Paraguas. In Chile is known from Conguillio National Park to Aysén (XI Region).

(White \& James 1988, Quilhot et al. 2012).

\section{Nephroma kuehnemannii I.M. Lamb}

Endemic to southern South America. The species grows on bark of Nothofagus spp. and shrubs, confined to humid and shaded sites in Los Paraguas. In Chile is known from Conguillio National Park to Aysén (XI Region).

(White \& James 1988; Quilhot et al. 2012).

\section{Nephroma microphyllum Henssen}

Endemic to southern South America. The species is an epiphyte of trees and shrubs in open, humid and shady sites. It was collected in Los Paraguas. In Chile is known from Temuco (IX Region) to Aysén (XI Region).

(White \& James 1988, Quilhot et al. 2012).

Nephroma parile (Ach.) Ach.
Cosmopolitan. The species is an epiphyte in Nothofagus forests in rather open sites in Los Paraguas. In Chile is known from Conguillio National Park to Aysén Region.

(White \& James 1988, Quilhot et al. 2012).

Nephroma skottsbergii F.J. White \& P. James

Endemic to southern South America. The species is an epiphyte of trees and shrubs in humid habitats, such as Laguna Arcoiris and Los Carpinteros. In Chile is known from Conguillio National Park to Aysén Region.

(White \& James 1988, Quilhot et al. 2012).

Normandina pulchella (Borrer) Nyl.

Cosmopolitan. The species is found on bark of trunks of Nothofagus, near El Hoyón, in high humidity and shade conditions. In Chile is known in Juan Fernández Archipelago, and from Mocha Island (VIII Region) to Magallanes (XII Region).

(Galloway 1985, Quilhot et al. 2010).

Ochrolechia pallescens (L.) A. Massal.

Widely distributed in Europe, North and South America, Australia and Antarctica. The species is an epiphyte of Nothofagus spp. in open sites in Laguna Captrén, El Hoyón and Laguna Verde. In Chile is known from Limarí and Fray Jorge National Park (IV Region), and from Nuble (VIII Region) to Navarino Island (XII Region).

(Redón \& Quilhot 1977, Messuti \& Lumbsch 2000).

Pannaria conoplea (Ach.) Bory

Pantemperate. The species has been collected from bark of Austrocedrus chilensis, also on mosses in open sites in scoria boulders on lava flows near Laguna Verde. In Chile is known from Antuco (VIII Region) to Aysén (XI Region). (Galloway et al. 2006, Quilhot et al. 2012).

Pannaria farinosa Elvebakk \& J. Fritt Rasm.

Panaustral. The species is an epiphyte in Nothofagus forests and shrubs, also on mosses and rocks, in both humid areas from Laguna Arcoiris to Laguna Captrén, and in open and drier sites, such as the scoria boulders on lava flows near Laguna Verde on bark of Austrocedrus chilensis. It is one of the most common species of the genus growing in the Park. In Chile is known in Fray Jorge National Park (IV Region), Juan Fernández Archipelago, and from Altos de Lircay National Reserve (VII Region) to Navarino Island (XII Region).

(Redón \& Quilhot 1977, Elvebakk et al. 2007).

Pannaria hispidula (Nyl.) Hue

Cosmopolitan. The species is an epiphyte on trunks of Nothofagus spp. in sites with high humidity. It was collected on trunks of Nothofagus pumilio on the roadside to Velo de la Novia. In Chile is known from Valdivia (X Region) to 
Navarino Island (XII Region).

(Redón \& Quilhot 1977, Jørgensen 2006, Passo et al. 2008).

Pannaria implexa (Stirt.) Passo, Calvelo \& Stenroos Austral. The species is an epiphyte of Nothofagus spp. and shrubs, also on rocks, soil and amongst mosses in sites with high humidity. It has been collected on bark of Nothofagus pumilio near Velo de la Novia, and in a humid and shaded site on the roadside to Laguna Verde. In Chile is known in Juan Fernández Archipelago, and from Villarrica (IX Region) to Magallanes (XII Region).

(Passo et al. 2008).

Pannaria microphyllizans (Nyl.) P.M. Jørg.

Austral. The species is an epiphyte of Nothofagus spp., also on rotten wood in habitats with high humidity. In Chile is known from Huerquehue National Park (IX Region) to Aysén (XI Region).

(Passo et al. 2008, Quilhot et al. 2012).

Pannaria pallida (Nyl.) Hue

Austral. The species is an epiphyte of Nothofagus spp. and shrubs in moderate light conditions. From 1970 to 1990, it was one of the commonest species in Nothofagus antarctica forests in El Hoyón and La Caseta. In Chile is known from Altos de Lircay National Reserve (VII Region) to Navarino Island (XII Region).

(Redón \& Quilhot 1977, Jørgensen 2006, Quilhot pers. comm.).

Pannaria sphinctrina (Mont.) Tuck.

Cosmopolitan. The species grows on bark of Nothofagus pumilio and shrubs, also on mosses, in habitats with high humidity. It has been collected in Velo de la Novia, Los Carpinteros and in a very shaded site near Laguna Verde. In Chile is known in Juan Fernández Archipelago, and from Valdivia (X Region) to Tierra del Fuego (XII Region).

(Elvebakk 2007).

Pannaria tavaresii P.M. Jørg.

The species has a warm-temperate, subtropical distribution. It is an epiphyte on trees, also on mosses and rocks in open sites. It was collected on bark of Austrocedrus chilensis in scoria boulders on lava flows near Laguna Verde. In Chile is known from Laguna del Laja National Park (VIII Region) to Aysén (XI Region).

(Galloway et al. 2006, Quilhot et al. 2012).

Pannoparmelia angustata (Pers.) Zahlbr.

Austral. The species grows on bark of Nothofagus spp. and shrubs in open sites. In Chile is known from Bio-Bio (VIII Region) to Magallanes (XII Region).

(Galloway 1985).
Parmelia cunninghamii Cromb.

Austral. The species is an epiphyte of Araucaria araucana, Nothofagus spp. and shrubs in areas of high humidity, from the Centro de Información to Laguna Captrén. In Chile is known from Ñuble (VIII Region) to Magallanes and the Antarctic Territory (XII Region).

(Galloway 1985, Øvstedal \& Lewis Smith 2001).

\section{Parmelia protosulcata Hale}

Austral. It is an epiphyte of Araucaria araucana, Nothofagus spp. and shrubs in open sites, widely distributed in the Park. In Chile is known from Termas de Chillán (VIII Region) to Magallanes (XII Region).

(Galloway 1985, Adler \& Calvelo 2002).

Parmelia saxatilis (L.) Ach.

Cosmopolitan. The species is an epiphyte of Araucaria araucana, also on rocks in open sites. In Chile is known from La Campana National Park (V Region), and from Malleco (IX Region) to Navarino Island and the Antarctic Territory (XII Region).

(Redón \& Quilhot 1977, Redón \& Walkowiak 1978; Øvstedal \& Lewis Smith 2001).

\section{Parmelia sulcata Taylor}

Cosmopolitan. The species is an epiphyte of trees and shrubs in open sites, such as Laguna Captrén, El Hoyón and La Caseta. In Chile is known from Valparaíso (V Region) to Navarino Island and the Antarctic Territory (XII Region). (Redón \& Quilhot 1977, Øvstedal \& Lewis Smith 2001).

\section{Parmeliella granulata I.M. Lamb}

The species is present in Oceania and Central and South America. It is an epiphyte of Nothofagus spp., also amongst mosses. It was collected in Los Paraguas, in a rather open site. In Chile is known from Altos de Lircay National Reserve (VII Region) to Aysén (XI Region).

(Jørgensen \& Galloway 1992, Galloway 2007)

Parmeliella nigrocincta (Mont.) Müll. Arg.

Austral. The species is an epiphyte in Nothofagus forests. It was collected in Los Paraguas. In Chile is known in Juan Fernández Archipelago, and from Malleco (IX Region) to Magallanes (XII Region).

(Galloway 1985).

\section{Parmeliopsis hyperopta (Ach.) Arnold}

Circumpolar (North America, Europe and northern Asia). The species is an epiphyte of trees and shrubs in open and humid sites. It was collected on bark of Nothofagus spp. near Laguna Captrén. In Chile is known from Río de Los Cipreses National Reserve (VI Region) to Magallanes (XII Region).

(Ryan 2002). 
Parmotrema arnoldii (Du Rietz) Hale

Pantropical, extending to into temperate regions to the north and south. The species grows on bark of Araucaria araucana, Nothofagus spp., shrubs and among mosses in rather shaded sites. In Chile is known from Altos de Lircay National Reserve (VII Region) to Llanquihue (X Region). (Galloway 1985, Nash III \& Elix 2002a).

\section{Parmotrema crinitum (Ach.) M. Choisy}

Pantropical and pantemperate. The species is currently found on bark of Araucaria araucana, Austrocedrus chilensis and Nothofagus spp. in open sites. In Chile is known from Altos de Lircay National Reserve (VI Region) to Llanquihue (X Region).

(Nash III \& Elix 2002a).

Parmotrema perlatum (Huds.) M. Choisy

Pantemperate. The species is an epiphyte on Araucaria araucana and Nothofagus spp. In Chile is known from Chillán (VIII Region) to Magallanes (XII Region).

(Nash III \& Elix 2002a).

Peltigera collina (Ach.) Schrad.

Circumpolar. The species grows on trunks and amongst mosses in open sites. It was collected from the base of trunks of Nothofagus antarctica in El Hoyón. In Chile is known from Cautín (IX Region) to Magallanes (XII Region).

(Goward et al. 1995, Martínez et al. 2003).

Peltigera lepidophora (Vain.) Bitter

Cicumpolar. The species is an epiphyte in trunks of Nothofagus spp., also on soil, amongst mosses and rotten wood. It was collected on bark of Nothofagus antarctica in Laguna Captrén. In Chile is known from Malleco (IX Region) to Magallanes (XII Region).

(Goward et al. 1995, Martínez et al. 2003).

Peltigera polydacton (Neck.) Hoffm.

Cosmopolitan. The species grows on the base of trunks of Nothofagus antarctica. In Chile is known in La Campana National Park (V Region), and from Aysén Region to Navarino Island (XII Region).

(Redón \& Quilhot 1977, Redón \& Walkowiak 1978, Martínez et al. 2003).

Pertusaria velata (Turner) Nyl.

Cosmopolitan. The species grows on bark of Nothofagus spp., occasionally on rocks. In Chile is known in Juan Fernández Archipelago, Santiago (Región Metropolitana) and Rancagua (VI Region), and from Cauquenes (VII Region) to Magallanes (XII Region).

(Messuti 2005).

Phlyctis chilensis D.J. Galloway \& Guzmán
Endemic to southern South America. It grows on Nothofagus trunks in shady and moist habitats. It was collected in Los Paraguas and near Laguna Arcoiris. In Chile is known from Los Queñes (VII Region) to Magallanes (XII Region).

(Galloway \& Guzmán Grimaldi 1988).

Physma chilense Hue.

The species is known in Chile, New Zealand and Tasmania. It grows on bark of Nothofagus spp. in open sites. In Chile is known in Juan Fernández Archipelago, and from Altos de Lircay National Reserve (VII Region) to Aysén (XI Region). (Verdon et al. 1992, Quilhot et al. 2012).

Platismatia glauca (L.) W.L. Culb. \& C.F. Culb.

Cosmopolitan. The species is an epiphyte of Araucaria araucana, Nothofagus spp. and shrubs, and currently found in the Park. In Chile is known in La Campana National Park (V Region), and from Altos de Lircay National Reserve (VII Region) to Navarino Island and the Antarctic Territory (XII Region).

(Culberson \& Culberson 1968, Redón \& Quilhot 1977, Redón \& Walkowiak 1978, Øvstedal \& Lewis Smith 2001).

Protousnea alectoroides (Mont.) Krog

Endemic to southern South America. An epiphyte on bark of trees and shrubs, rare in the Park. In Chile is known from Nahuelbuta National Park (IX Region) to Aysén (XI Region). (Krog 1976, Calvelo et al. 2005).

Protousnea dusenii (D.R.) Krog

Endemic to southern South America. It is an epiphyte on trunks and twigs of Araucaria araucana and Nothofagus spp. in open sites and widely distributed in the Park. In Chile is known from Aysén Region to Navarino Island (XII Region).

(Krog 1976, Redón \& Quilhot 1977, Calvelo et al. 2005).

Protousnea magellanica (Mont.) Krog

Endemic to southern South America. It is an epiphyte on tree trunks, particularly on Araucaria araucana and Nothofagus antarctica in open sites. In Chile is known from Altos de Lircay National Reserve (VII Region) to Navarino Island (XII Region).

(Krog 1976, Redón \& Quilhot 1977, Calvelo et al. 2005).

\section{Protousnea malacea (Stirt.) Krog}

Endemic to southern South America. It is an epiphyte on trees in open sites. It is widely distributed in the Park. In Chile is known from Altos de Lircay National Reserve (VII Region) to Navarino Island (XII Region).

(Krog 1976, Redón \& Quilhot 1977, Calvelo et al. 2005).

Protousnea poeppigii (Nees \& Flot.) Krog

Endemic to southern South America. The species is an 
epiphyte on Araucaria araucana and Nothofagus spp. It is widely distributed in the Park. In Chile is known from Antuco (VIII Region) to Magallanes (XII Region).

(Krog 1976, Calvelo et al. 2005).

\section{Protousnea teretiuscula Krog}

Endemic to southern South America. The species is an epiphyte on tree trunks and shrubs. In Chile is known from Nahuelbuta National Park (IX Region) to Aysén (XI Region). (Krog 1976, Calvelo et al. 2005).

Pseudocyphellaria berberina (G. Forst.) D.J. Galloway \& P. James

Endemic to southern South America. The species is an epiphyte on tree trunks and shrubs, also grows on the ground and mosses, in very humid conditions. It has been collected on trunks of Nothofagus spp. and in shrubs on the roadside to Laguna Captrén and Laguna Arcoiris. In Chile is known in Juan Fernández Archipelago, and from Mocha Island (VIII Region) to Tierra del Fuego (XII Region). (Galloway 1992, Quilhot et al. 2010).

Pseudocyphellaria coerulescens (Mont.) H. Magn. Endemic to southern South America. The species is an epiphyte on tree trunks and shrubs in humid and shaded habitats. It was collected on the roadside to Velo de la Novia. In Chile is known in Juan Fernández Archipelago, and from Mocha Island (VII Region) to Tierra del Fuego (XII Region).

(Galloway 1992, Quilhot et al. 2010).

Pseudocyphellaria compar (Nyl.) H. Magn.

Endemic to southern South America. The species is an epiphyte on trunks of Araucaria araucana and Nothofagus spp., also in shrubs in moist and shaded sites. In Chile is known from Mocha Island (VIII Region) to Tierra del Fuego (XII Region).

(Galloway 1992, Quilhot et al. 2010).

Pseudocyphellaria coriifolia (Müll. Arg.) Malme

Endemic to southern South America. The species is an epiphyte on Araucaria araucana, Nothofagus spp. and shrubs in moderate to high light and humid conditions, in a wide variety of habitats. It appears to be the commonest species of Pseudocyphellaria in the Park. In Chile is known in Juan Fernández Archipelago, and from Chillán (VIII Region) to Navarino Island (XII Region).

(Redón \& Quilhot 1977, Galloway 1992).

Pseudocyphellaria crocata (L.) Vain.

Cosmopolitan. The species is an epiphyte of Araucaria araucana and Nothofagus spp. in a wide variety of habitats, also on scoria boulders on lava flows near Laguna Verde. In Chile is known in Juan Fernández Archipelago, Fray
Jorge National Park (IV Region), and from Altos de Lircay National Reserve (VII Region) to Navarino Island (XII Region).

(Redón \& Quilhot 1977, Galloway 1992).

Pseudocyphellaria dasyphyllidia Bjerke

Endemic to southern South America. The species is an epiphyte of trees and shrubs in a wide variety of habitats. In Chile is known from Cauquenes (VII Region) to Magallanes (XII Region).

(Bjerke et al. 2003b).

Pseudocyphellaria dubia Du Rietz.

Endemic to southern South America. The species is rare in the Park. It grows on bark of Nothofagus spp. in deep shade habitats of high humidity. It was collected on the road side to Velo de la Novia. In Chile is known from Malleco (IX Region) to Navarino Island (XII Region).

(Redón \& Quilhot 1977, Galloway 1992).

Pseudocyphellaria faveolata (Delise) Malme

Austral. The species is an epiphyte of Araucaria araucana and Nothofagus spp., in open and high-light habitats. In Chile is known from Nahuelbuta National Park (IX Region) to Magallanes (XII Region).

(Galloway 1992).

Pseudocyphellaria flavicans (Hook \& Taylor) Vain.

Endemic to southern South America. The species is an epiphyte on Araucaria araucana and Nothofagus spp. in open and high-light habitats. It is widely distributed in the Park. In Chile is known in Juan Fernández Archipelago, and from Mocha Island (VIII Region) to Tierra del Fuego (XII Region).

(Galloway 1992, Quilhot et al. 2010).

Pseudocyphellaria glabra (Hook. f. \& Taylor) C.W. Dodge Panaustral. The species is an epiphyte of Nothofagus spp., dead vegetation on rather humid and shaded sites such as the roadside to Velo de la Novia and near Laguna Arcoiris. In Chile is known in Juan Fernández Archipelago, and from Mocha Island (VIII Region) to Tierra del Fuego (XII Region).

(Galloway 1992, Quilhot et al. 2010).

\section{Pseudocyphellaria granulata (C. Bab.) Malme}

Austral. The species is an epiphyte on Araucaria araucana and Nothofagus spp. It is widely distributed in the Park in fairly open conditions with relatively high light intensity. In Chile is known from Nahuelbuta National Park (IX Region) to Navarino Island (XII Region).

(Redón \& Quilhot 1977, Galloway 1992).

Pseudocyphellaria guillemini (Mont.) D.J. Galloway 
Endemic to southern South America. The species is an epiphyte of Nothofagus spp. in rather low-light situations. It has been collected in Laguna Captrén. In Chile is known in Juan Fernández Archipelago, and from Conguillio National Park to Magallanes (XII Region).

(Galloway 1992).

\section{Pseudocyphellaria guzmanii D. J. Galloway}

Endemic to southern South America. The species is found on trunks of Nothofagus spp. in Laguna Captrén and Los Paraguas, in open forests. In Chile is known from Conguillio National Park to Puyehue National Park (X Region).

(Galloway 1992).

Pseudocyphellaria hirsuta (Mont.) Malme

Endemic to southern South America. The species is an epiphyte of Araucaria araucana and Nothofagus spp. in a wide range of habitats. In Chile is known in Juan Fernández Archipelago, and from Constitución (VII Region) to Tierra del Fuego (XII Region).

(Galloway 1992).

Pseudocyphellaria intricata (Delise) Vain.

Cosmopolitan. The species is an epiphyte of Araucaria araucana, Nothofagus spp. and shrubs on the roadside to Laguna Captrén and to Laguna Verde, in humid and moderate to dense shade habitats, also in scoria boulders on lava flows. In Chile is known in Juan Fernández Archipelago, and from Fray Jorge National Park (IV Region) to Tierra del Fuego (XII Region).

(Galloway 1992).

Pseudocyphellaria lechleri (Müll. Arg.) Du Rietz.

Endemic to southern South America. The species occurs sporadically as an epiphyte of Araucaria araucana and Nothofagus spp. In Chile is known from Conguillio National Park to Tierra del Fuego (XII Region).

(Galloway 1992).

Pseudocyphellaria mallota (Tuck.) H. Magn.

Endemic to southern South America. The species is an epiphyte of trees and shrubs in humid and moderate light situations. It was collected on bark of Nothofagus spp. in Los Paraguas. In Chile is known in Fray Jorge National Park (IV Region), Juan Fernández Archipelago, and from Conguillio National Park to Magallanes (XII Region). (Galloway 1992).

Pseudocyphellaria neglecta (Müll. Arg.) H. Magn.

Austral. The species is an epiphyte of trees and shrubs in dryish habitats with a high light intensisty. It was collected near La Caseta. In Chile is known from La Campana National Park (V Region) to Tierra del Fuego (XII Region). (Redón \& Walkowiak 1978; Galloway 1992).
Pseudocyphellaria nitida (Taylor) Malme

Endemic to southern South America. It is an epiphyte of Nothofagus spp. It was collected near El Hoyón and Laguna Captrén, in moderate to high-light habitats. In Chile is known in Juan Fernández Archipelago, and from Mocha Island (VIII Region) to Magallanes (XII Region).

(Galloway 1992, Quilhot et al. 2010).

Pseudocyphellaria norvegica (Gyeln.) P. James

Cosmopolitan. The species is an epiphyte of trees and shrubs in humid habitats, and was collected on bark of Nothofagus spp. in Los Paraguas. In Chile is known in Juan Fernández Archipelago, and from Mocha Island (VIII Region) to Aysén (XI Region).

(Galloway 1992, Quilhot et al. 2010).

Pseudocyphellaria nudata (Zahlbr.) D.J. Galloway Endemic to southern South America. The species is currently found on trunks of Nothofagus antarctica and N. pumilio, mainly in drier and moderate to high-light conditions. In Chile is known from Chillán (VIII Region) to Aysén (XI Region). (Galloway 1992).

Pseudocyphellaria obvoluta (S.W. ex Ach.) Malme Endemic to southern South America. The species is an epiphyte of trees and shrubs in forests in Laguna Captrén. In Chile is known from Nahuelbuta National Park (IX Region) to Navarino Island (XII Region).

(Redón \& Quilhot 1977, Galloway 1992).

\section{Pseudocyphellaria pilosella Malme}

Endemic to southern South America. The species is an epiphyte of Nothofagus spp. in moist humid, rather lowlight habitats. In Chile is known from Chillán (VIII Region) to Aysén (XI Region).

(Galloway 1992).

Pseudocyphellaria piloselloides (Räsänen) H. Magn.

Endemic to southern South America. The species has been collected on bark of Araucaria araucana and Nothofagus spp. in Laguna Captrén, in open forests. In Chile is known from Conguillio National Park to Tierra del Fuego (XII Region).

(Galloway 1992).

Pseudocyphellaria pluvialis R. Sant.

Endemic to southern South America. The species is an epiphyte of trees and shrubs on the roadside to Los Carpinteros and on the roadside to Velo de la Novia, in very humid, shaded habitats. In Chile is known from Mocha Island (VIII Region) to Aysén (XI Region). (Galloway 1992, Quilhot et al. 2010).

Pseudocyphellaria redonii D.J. Galloway 
Endemic to southern South America. The species is an epiphyte of trees and shrubs in shaded, humid habitats. It was collected in Los Paraguas. In Chile is known from Cautín (IX Region) to Magallanes (XII Region).

(Galloway 1992).

Pseudocyphellaria santessonii D.J. Galloway

Endemic to southern South America. It is an epiphyte of Araucaria araucana and Nothofagus spp. It was collected near Cabañas del Lago, in a humid and moderate light habitat. In Chile is known in Juan Fernández Archipelago, and from Mocha Island (VIII Region) to Magallanes (XII Region).

(Galloway 1992, Quilhot et al. 2010).

Pseudocyphellaria scabrosa R. Sant.

Endemic to southern South America. The species is widely distributed in the Park and grows on bark of Araucaria araucana, Nothofagus spp. and shrubs. In Chile is known from Mocha Island (VIII Region) to Navarino Island (XII Region).

(Redón \& Quilhot 1977, Galloway 1992).

Pseudocyphellaria wandae D.J. Galloway

Endemic to southern South America. It has been collected from bark of Araucaria araucana and Nothofagus antarctica near El Hoyón, in a humid and moderate shaded habitat. In Chile is known from Constitución (VII Region) to Magallanes (XII Region).

(Galloway 1992).

\section{Psoroma aphthosum Vain.}

Austral. The species is currently found on bark of old Nothofagus dombeyi on the roadside from Centro de Información to Laguna Captrén. In Chile is known from Conguillio National Park to Vicente Pérez Rosales National Park (X Region).

(Redón 1974, Jørgensen 2006).

\section{Psoroma caliginosum Stirt.}

Australasian. The species is an epiphyte of Nothofagus pumilio in rather humid habitats. In Chile is known from Malleco (IX Region) to Valdivia (X Region).

(Jørgensen 2006).

\section{Psoroma fruticulosum P. James \& Henssen}

The species is known in South America, Subantarctic Islands, New Zealand and South Africa. It is an epiphyte on twigs and small branches of trees and shrubs, also on soil in humid and shaded habitats. It was collected on bark of Nothofagus pumilio on the roadside to Velo de la Novia. In Chile is known from Conguillio National Park to Magallanes and the Antarctic Territory (XII Region).

(Jørgensen \& Galloway 1992, Øvstedal \& Lewis Smith 2001).
Psoroma hypnorum (Vahl) S.F. Gray

Bipolar. The species is an epiphyte on twigs and small branches of trees and shrubs, also on soil in humid and shaded habitats. It has been collected on bark of Nothofagus antarctica and $N$. pumilio in El Hoyón. In Chile is known from Altos de Lircay National Reserve (VII Region) to Magallanes and the Antarctic Territory (XII Region). (Øvstedal \& Lewis Smith 2001, Quilhot et al. 2010).

Psorophorus fueguiensis (Zahlbr.) Elvebakk \& S.G. Hong Endemic to southern South America. The species is an epiphyte of forest trees and shrubs, in humid and shaded habitats. It has been collected on bark of Nothofagus spp. in Velo de la Novia and on the roadside to Sierra Nevada. In Chile is known in Juan Fernández Archipelago, and from Conguillio National Park to Aysén (XI Region).

(Elvebakk et al. 2010).

\section{Psorophorus pholidotus Elvebakk \& S.G. Hong}

Austral. The species is an epiphyte on trees and shrubs in humid and shaded habitats. It has been collected on bark of Nothofagus spp. on the road side to Los Carpinteros and on the roadside to Velo de la Novia. In Chile is known in Juan Fernández Archipelago, and from Conguillio National Park to Magallanes (XII Region).

(Elvebakk et al. 2010).

Punctelia subrudecta (Nyl.) Krog

Cosmopolitan. The species is an epiphyte of Nothofagus spp. and also on rocks. It was collected on bark of Nothofagus antarctica near Laguna Captrén. In Chile is known from Mocha Island (VIII Region) to Magallanes (XII Region). (Galloway 1985).

Rimelia reticulata (Taylor) Hale \& A. Flechter Cosmopolitan. The species is an epiphyte of Nothofagus spp. present in a wide variety of habitats. In Chile is known from Altos de Lircay National Reserve (VII Region) to Aysén (XI Region).

(Nash III \& Elix 2002b).

Sticta caulescens De Not.

Endemic to southern South America. The species is an epiphyte of trees and shrubs, also on soil in very humid and often deeply shaded habitats. It is currently found in Laguna Arcoiris. In Chile is known from Mocha Island (VIII Region) to Magallanes (XII Region).

(Galloway 1994, Quilhot et al. 2010).

Sticta fuliginosa (Hoffm.) Ach.

Cosmopolitan. The species is an epiphyte of bark and twigs of Nothofagus spp. and shrubs in rather drier habitats. In Chile is known in Putre (I Region), and from Fray Jorge National Park (IV Region) to Magallanes (XII Region). 
(Galloway 1994, Herrera pers. comm.).

Sticta hypochra Vain.

Endemic to southern South America. The species is an epiphyte in Nothofagus forests, also on shrubs and amongst mosses and rotten wood. It was collected in Los Paraguas. In Chile is known from Conguillio National Park to Navarino Island (XII Region).

(Redón \& Quilhot 1977, Galloway 1994).

Sticta limbata (Sm.) Ach.

Cosmopolitan. The species is an epiphyte on Araucaria araucana and Nothofagus spp. near Laguna Arcoiris. In Chile is known from Mocha Island (VIII Region) to Tierra del Fuego (XII Region).

(Galloway 1994, Quilhot et al. 2010).

Sticta longipes (Müll. Arg.) Malme

Endemic to southern Chile. The species is present in humid and shaded habitats. It has been collected on bark of Nothofagus pumilio on the roadside to Velo de la Novia. In Chile is known from Mocha Island (VIII Region) to Aysén (XI Region).

(Galloway 1994, Quilhot et al. 2010).

Sticta weigelii (Ach.) Vainio

Cosmopolitan. The species is found on trunks of Nothofagus spp. and shrubs, also on soil in fairly open habitats in areas of high humidity, such as Laguna Arcoiris. In Chile is known in Fray Jorge National Park (IV Region) and from Conguillio National Park to Navarino Island (XII Region). (Redon \& Quilhot 1977, Galloway 1994).

Teloschistes chrysophthalmus (L.) Th. Fr.

Cosmopolitan. The species is an epiphyte of trees and shrubs. It was collected on bark of Nothofagus spp., in an open site near Laguna Captrén. In Chile is known from Cerro Moreno (II Region) to Puerto Montt (X Region).

(Galloway 1985).

Tukermannopsis chlorophylla (Willd.) Hale

Bipolar. The species is an epiphyte of Araucaria araucana and Nothofagus spp. in rather drier habitats. It is very common in Laguna Captrén. In Chile is known from La Campana National Park (V Region) to Navarino Island (XII Region).

(Redón \& Quilhot 1977, Redón \& Walkowiak 1978, Kärnefelt et al. 1992).

Usnea pusilla (Räsänen) Räsänen

Austral. The species is an epiphyte of Nothofagus antarctica in open sites such as El Hoyón and La Caseta. In Chile is known in Fray Jorge National Park (IV Region), Quebrada Alvarado (V Región), and from Altos de Lircay National
Reserve (VII Region) to Llanquihue (X Region).

(Redón 1974, Galloway 1985).

Usnea rubicunda Stirt.

Cosmopolitan. It grows on bark of Nothofagus spp. in rather shaded and humid habitats. In Chile is known from Iquique (I Region) to Aysén (XI Region).

(Galloway 1985).

Xhanthopsoroma contextum (Stirt.) Elvebakk

Austral. The species is an epiphyte of Nothofagus pumilio. It was collected on the roadside to Velo de la Novia, in an habitat of high humidity. In Chile is known in Juan Fernández Archipelago, and from Malleco (IX Region) to Magallanes (XII Region).

(Elvebakk et al. 2010).

Xanthopsoroma soccatum (R. Br. ex Cromb.) Elvebakk Australasian. The species grows on shrubs and trees, also on mosses, near Velo de la Novia. In Chile is known in Juan Fernández Archipelago and from Villarrica (IX Region) to Aysén (XI Region).

(Elvebakk et al. 2010).

\section{ACKNOWLEDGMENTS}

We are much grateful to David J. Galloway (Landcare Research, New Zealand); Jarle W. Bjerke and Arve Elvebakk (University of Tromsø, Norway); and Peter W. James (British Museum) for their assistance in the taxonomic work. Our gratitude to CONAF IX Región, Chile, especially to the staff of Departamento de Áreas Silvestres Protegidas and Park Rangers, for their kindness and logistical assistance. We thank the Dirección de Investigación, Universidad de Valparaíso, for the granted funds to this research.

\section{REFERENCES}

Adler, M. \& S. Calvelo. 1996. Two new species of the genus Menegazzia (Parmeliaceae sensu lato, lichenized Ascomycota) from southern South America. Mycotaxon 59: 367-372.

Adler, M. \& S. Calvelo. 2002. Parmeliaceae species (lichenized Ascomycetes) from Tierra del Fuego (southern South America) and their world distribution patterns. In: A. Thell $\&$ T. Feuerer (eds.), Biodiversity and Ecology Proceedings of the Fourth Meeting of Latin American Lichenologists. GLAL-4. Mitteilungen aus dem Institut für Allgemeine Botanik, Hamburg 30-32: 9-24.

Arriagada, C. \& C. Cares. 1996. Flora y fitosociología del Parque Nacional Conguillío. Tesis. Escuela de Ingeniería Forestal, Universidad de Temuco, Temuco.Chile.

BJerke, J.W. 2001. A new soredite species of Menegazzia (Parmeliaceae, lichenized Ascomycota) from Chile. 
Lichenologist 33: 117-120.

BJerke, J.W. 2005. Synopsis of the lichen genus Menegazzia (Parmeliaceae. Ascomycota) in South America. Mycotaxon 81: 423-454.

BJERKE, J.W \& A. ELVEBAKK. 2001. The sorediate species of the genus Menegazzia (Parmeliaceae, lichenized Ascomycotina) in southernmost South America. Mycotaxon 78: 363-392.

BJerke, J.W., A. Elvebakk \& W. Quilhot. 2003a. Distribution and habitat ecology of the sorediate species of Menegazzia (Parmeliaceae, lichenized Ascomycota) in Chile. Revista Chilena de Historia Natural 76: 79-98.

BJerke, J.W., D.J. Galloway, A. Elvebakk \& W. Quilhot. 2003b. Pseudocyphellaria dasyphyllidia - a new phyllidiate species from Chile (Lobariaceae, lichenized Ascomycota). Cryptogamie, Mycologie 24: 59-66.

Blanco, O., A. Crespo, P.K. Divakar, T.L. Esslinger, D.L. Hawksworth \& H.T. Lumbsch. 2004. Melanelixia and Melanohalea, two new genera segregated from Melanelia (Parmeliaceae) based on molecular and morphological data. Mycological Research 108: 873-884.

Brodo, I.M. \& D.L. Hawksworth. 1977. Alectoria and allied genera in North America. Opera Botanica 42: 1-164.

Brusse, E.A. \& I. Kärnefelt. 1991. The new Southern Hemisphere genus Coelopogon (Lecanorales, Ascomycotina) with a new species from South Africa. Mycotaxon 42: 35-41.

Calvelo, S., E. Stocker-Wörgötter, S. Liberatore \& J.A. Elix. 2005. Protousnea (Parmeliaceae, Ascomycota) a genus endemic to southern South America. Bryologist 108: 1-15.

Culberson, W.L. \& C.F. Culberson. 1968. The lichen genera Cetrelia and Platismatia (Parmeliaceae). Contribution to the U.S. National Herbarium 34: 449-558.

Dinerstein, E., D.M. Olson, A.L.Webster, S.A. Primm, M.P. Bookbinder \& G. LeDEC. 1995. A conservation assessment of the terrestrial ecoregions of Latin America and the Caribbean. The World Bank, Washington DC.

Ekman, S. \& P.M.Jørgensen. 2002. Towards a molecular phylogeny for the lichen family Pannariaceae. Canadian Journal of Botany 89: 625-634.

Elix, J.A. 1992. Hypogymnia. Flora of Australia 54: 201-213.

Elix, J.A. \& P.M. McCARThy. 1998. Catalogue of the lichens of the smaller Pacific Islands. Bibliotheca Lichenologica $70: 1-361$.

Elvebakk, A. 2007. The panaustral lichen Pannaria sphinctrina (Mont.) Tuck. and the related new species P. lobulifera from New Caledonia. Cryptogamie, Mycologie 28: 225235.

ElvebakK, A. \& D.J. Galloway. 2003. Notes on the heterogeneous genus Psoroma in New Zealand. Australasian Lichenology 53: 4-9.

Elvebakk, A., J. Fritt-Rasmussen \& J.A. Elix. 2007. The New Zealand lichen Pannaria leproloma (Nyl.) P.M. Jørg. and its panaustral relative $P$. farinosa nom. nov. Lichenologist 39: 349-359.

Elvebakk, A., E.H. Robertsen, Ch.H. Park \& S.G. Hong. 2010. Psorophorus and Xanthopsoroma, two new genera for yellow-green, corticolous and squamulose lichen species, previously in Psoroma. Lichenologist 42: 563-585.

Filson, R.B. 1992. Collema. Flora of Australia 54: 161-173.

Gajardo, R. 1983. Sistema básico de clasificación de la Vegetación Nativa Chilena. Ministerio de Agricultura. Corporación
Nacional Forestal. Universidad de Chile. 319 pp.

Galloway, D.J. 1983. New taxa in the New Zealand lichen flora. New Zealand Journal of Botany 21: 191-199.

GallowaY, D.J. 1985. Flora of New Zealand Lichens. P.D. Hasselberg, Government Printer, Wellington, New Zealand. $662 \mathrm{pp}$.

Galloway, D.J. 1992. Studies in Pseudocyphellaria (lichens) III. The South American species. Bibliotheca Lichenologica 46: 1- 275.

GallowaY, D.J. 1994. Studies on the lichen genus Sticta (Schrreber) Ach. I. Southern South American species. Lichenologist 26: $223-282$.

Galloway, D.J. 1998. The lichens of Chile: present knowledge and future prospects. In: M.P. Marcelli \& M.R.D. Seaward (eds.), Lichenology in Latin America: history, current knowledge and applications, pp. 87-100. CETESB. Sao Paulo.

Galloway, D.J. 2007. Flora of New Zealand Lichens. Revised Second Edition including lichen-forming and lichenicolous fungi. Vol. 1 Manaaki Whenua Press. Lincoln., New Zealand. $1006 \mathrm{pp}$.

Galloway, D.J. \& P.W. James. 1985. The lichen genus Psoromidium Stirton. Lichenologist 17: 173-188.

Galloway, D.J. \& P.W. James. 1987. Metus, a new austral lichen genus and notes on an Australasian species of Pycnothelia. Notes from the Royal Botanical Garden Edinburgh 44: 561-570.

Galloway, D.J. \& G. Guzmán-Grimaldi. 1988. A new species of Phlyctis from Chile. Lichenologist 20: 393-397.

Galloway, D.J. \& P.M. Jørgensen. 1995. The lichen genus Leptogium (Collemataceae) in southern Chile. In: F.J.A. Daniels, M. Schultz \& J. Peine (eds.), Flechten Follmann. Contributions to Lichenology in honour of Gerhard Follmann; pp. 227-247. Geobotanical and Phytotaxonomical Study Group. Botanical Institut, University of Cologne, Cologne, Germany.

Galloway, D.J. \& W. Quilhot. 1998. Checklist of Chilean lichenforming and lichenicolous fungi. Gayana Botanica 55: 111-185.

Galloway, D.J., W. Quilhot \& P.M. Jørgensen. 2006. Pannaria conoplea and $P$. tavaresii (Ascomycota: Parmeliaceae) new to Chile. Lichenologist 38: 83-87.

Goward, T., B. Goffinet \& O.Vitikainen. 1995. Synopsis of the genus Peltigera (lichenized Ascomycetes) in British Columbia, with a key to the Northamerican species. Canadian Journal of Botany 73: 91-111.

HaLe, M.E. JR. 1974. Delimitation of the lichen genus Hypotrachyna (Vain.) Hale. Phytologia 28: 340-342.

Halonen, P., L. Myllys, S. Velmala \& H. Hyvärinen. 2009. Gowardia (Parmeliaceae) -a new alectorioid lichen genus with two species. Bryologist 112: 138-146.

Jørgensen, P.M. 2004. Further contributions to the Pannariaceae (lichenized Ascomycetes) of the Southern Hemisphere. Bibliotheca Lichenologica 31: 341-347.

Jørgensen, P.M. 2006. Conspectus familiae Pannariaceae (Ascomycetes lichenosae). Ilicifolia 4: 1-78.

Jørgensen, P.M. \& D.J. Galloway. 1992. Pannariaceae. Flora of Australia 54: 246-292.

Kärnefelt, I., Mattsson, J.E. \& A.Thell. 1992. Evolution and phylogeny of cetraroid lichens. Plant Systematics and 
Evolution 183: 113-160.

KroG, H. 1976. Lethariella and Protousnea, two new lichen genera in Parmeliaceae. Norwegian Journal of Botany 23:83-106.

LÜCKING, R. \& K. KALB. 2000. Foliikole Flechten aus Brasilien (vornehmlich Amazonien), inklusive einer Checkliste und Bemerkungen zu Coenogonium und Dimerella (Gyalectaceae). Botanische Jahrbücher 122: 1-61.

MahncKe, M. 1997. Estudio fitosociológico de la vegetación natural en el Parque Nacional Conguillío de la precordillera andina, Región de la Araucanía, Chile. Tesis. Escuela de Ingeniería Forestal, Universidad deTemuco. Chile.

Martínez, I., A.R. Burgaz, O. Vitikainen \& A. Escudero. 2003. Distribution patterns in the genus Peltigera Willd. Lichenologist 35: 301-323.

Messuti, M.I. 1996. Notes on the lichen genus Coccotrema in southern South America. New Zealand Journal of Botany 34: 57-64.

Messuti, M.I. 2005. The genus Pertusaria (Pertusariales, Pertusariaceae) in the Juan Fernández Archipelago. Lichenologist 37: 111-122.

Messuti, M.I. \& H.T. Lumbsch. 2000. A revision of the genus Ochrolechia in southern South America. Bibliotheca Lichenologica 75: 333-346.

Messuti, M.I., G. Vobis \& I.N. De La Rosa. 2007. First record of the lichen Metus pileatus in Argentina. In: I. Kärnefelt \& A. Thell (eds.), Lichenological Contributions in Honour of David Galloway, Bibliotheca Lichenologica 95:471-477. J. Cramer Berlin-Stuttgart.

Nash III, T.H. \& J.A. Elix. 2002a. Parmotrema. In: T.H. Nash III, B.D. Ryan, C. Gries \& F. Bungartz (eds.), Lichen Flora of the Sonoran Desert Region, Vol. 1, pp: 318-329. Lichens Unlimited, Arizona State University, Tempe, Arizona.

Nash III, T.H. \& J.A. Elix. 2002b. Rimelia. In: T.H. Nash III, B.D. Ryan, C. Gries \& F. Bungartz (eds.), Lichen Flora of the Sonoran Desert Region, Vol. 1, pp. 449-451. Lichens Unlimited, Arizona State University, Tempe, Arizona.

Nash III, T.H., SiPman H.G.M. \& J.A. Elix. 2002. Hypotrachyna. In: T.H. Nash III, B.D. Ryan, C. Gries \& F. Bungartz (eds.), Lichen Flora of the Sonoran Desert Region, Vol. 1, pp: 238-251. Lichens Unlimited, Arizona State University, Tempe, Arizona.

Øvstedal, D.O. \& R.I. Lewis Smith. 2001. Lichens of Antarctica and South Georgia. A Guide to their Identification and Ecology. Cambridge University Press. 411 pp.

Parmasto, E. 1978. The genus Dictyonema (Thelephorolichenes). Nova Hedwigia 29: 99-144.
Passo, A. \& S. Calvelo. 2006. New reports and combinations in the family Pannariaceae (Lecanorales, lichenized Ascomycota). Lichenologist 38: 549-555.

Passo, A., S. Stenroos \& S. Calvelo. 2008. Jorgensenia, a new genus to accommodate Psoroma cephalodium (lichenized Ascomycota). Mycological Research 112:1455-1474.

PrINTZEN, C. 2008. Uncharted terrein: the phylogeography of arctic and boreal lichens. Plant Ecology \& Diversity 2: 265-271.

Quilhot, W., C. Rubio \& J.W BJerke. 2002. El género Menegazzia (Parmeliaceae, Ascomycotina liquenizada) en Laguna San Rafael, Sur de Chile. Boletín Museo Nacional Historia Natural Chile 51: 81-84.

Quilhot, W., M. Cúllar, R. Díaz, F. Riquelme \& C. Rubio. 2010. Estudio preliminar de la flora liquénica de Isla Mocha, sur de Chile. Gayana Botanica 67: 194-200.

Quilhot, W., M., Cuéllar, R. Díaz, F. Riquelme \& C. Rubio. 2012. Lichens of Aysén, southern Chile. Gayana Botanica 69: 16-46.

Redón, J. 1974. Observaciones sistemáticas y ecológicas en líquenes del Parque Nacional Vicente Pérez Rosales. Anales del Museo de Historia Natural Valparaíso, Chile 7: 169-222.

Redón, J. \& W. Quilhot. 1977. Los líquenes de Isla Navarino. I. Estudio sistemático y ecológico preliminar. Serie Científica Instituto Antártico Chileno 5: 65-70.

Redón, J. \& A. WALKowiak. 1978. Estudio preliminar de la flora liquénica del Parque Nacional "La Campana". I. Resultados sistemáticos. Anales del Museo de Historia Natural de Valparaíso 11: 19-36.

Ryan, B.D. 2002. Parmeliopsis. In: T.H. Nash III, B.D. Ryan, C. Gries \& F. Bungartz (eds.), Lichen Flora of the Sonoran Desert Region, Vol. 1, pp. 315-317. Lichens Unlimited, Arizona State University, Tempe, Arizona.

Sipman, H.J.M. 1986. Notes on the lichen genus Everniastrum (Parmeliaceae). Mycotaxon 26: 235-251.

Stenroos, S. 1995. Cladoniaceae (Lecanorales, Lichenized Ascomycotina) in the flora of Chile. Gayana Botanica 52: 89-131.

Verdon, D., B. Filson \& A. Henssen. 1992. Collemataceae. Flora of Australia 54: 159-198.

Wedin, M. 1995. The lichen family Sphaerophoraceae (Caliciales, Ascomycotina) in temperate areas of the Southern Hemisphere. Symbolae Botanicae Upsaliensis 31: 1-102.

White, F.J. \& P.W. JAmES. 1988. Studies on the genus Nephroma II*, the southern temperate species. Lichenologist 20: 103166.

Recibido: 16.05 .12

Aceptado: 04.12.12 